\title{
The Open High School of Utah: Openness, Disaggregation, and the Future of Schools
}

David Wiley

david.wiley@gmail.com

Follow this and additional works at: https://scholarsarchive.byu.edu/facpub

Part of the Educational Psychology Commons

\section{Original Publication Citation}

Wiley, D. (29). The Open High School of Utah: Openness, Disaggregation, and the Future of Schools. Tech Trends.

\section{BYU ScholarsArchive Citation}

Wiley, David, "The Open High School of Utah: Openness, Disaggregation, and the Future of Schools" (2009). Faculty Publications. 129.

https://scholarsarchive.byu.edu/facpub/129 


\section{The Open High School of Utah:}

\section{Openness, Disaggregation, and the Future of Schools}

By David Wiley

\section{Utah's Charter Schools}

Historically, the purpose of charter schools has been to offer students (and their parents) alternatives regarding the curricular emphasis and pedagogical models that dominate their adolescent lives and, to a large extent, determine their future chances for education and employment.

Charter schools in Utah serve this same mission of providing choices. In the state of Utah, charter schools are public schools that receive state funding according to the number of students they enroll using exactly the same model as other public schools. Charter schools are generally subject to the same laws and regulations as other public schools, as per the Utah Charter School website:

Laws and regulations relating to religion in the schools, school fees and tuition, health and safety, civil rights, annual reports, prohibitions against advocacy of unlawful behavior, screening of potential employees or volunteers for competency and fitness, and most other matters are the same for both charter schools and other public schools.... Charter schools may only employ educators who hold valid teaching certificates or who meet State Board requirements for alternative certification or authorization (USOE, 2008).

While the charter movement has a rich history in Utah, virtual charters are a recent development. In 2007, a founding board consisting of faculty, staff, and graduate students in Utah State University's Center for Open and
Sustainable Learning prepared and submitted an application to create the state's second virtual charter, called the Open High School of Utah (OHSU). OHSU opens its virtual doors to ninth graders in the fall of 2009. While students are not yet through the virtual doors, OHSU still provides a glimpse at the ways in which openness, disaggregation, and the Internet will shape the future of schooling.

\section{The Open High School of Utah}

In addition to a firm belief that an environment of choice creates opportunities for students to find the school and program of study that fits them best, the Open High School of
"In the organization's charter documents, OHSU founders committed the school to using 'open educational resources' exclusively throughout the entire curriculum." Utah is dedicated to increasing access to high quality educational opportunity to everyone around the world. The core philosophy of the OHSU is that education is a universal human right and should be available to everyone. This philosophical position is complemented by the school's mantra of "focus on student learning and outsource everything else." These beliefs have significantly influenced the structure of the OHSU and its services into three areas: innovations in curriculum, innovations in organization, and innovations in technology.

Innovations in Curriculum

The primary mission of the OHSU is sup- 
porting its students in reaching their full potential as human beings; this comes as no surprise. However, the OHSU has a critically important secondary mission - devel-

"Because the Open Curriculum is openly licensed, any school anywhere in the world can adapt pieces of the curriculum (or the entire curriculum) at no cost." oping and disseminating the Open Curriculum.

The Open Curriculum is the most distinguishing characteristic of the Open High School of Utah. In the organization's charter documents, OHSU founders committed the school to using "open educational resources" exclusively throughout the entire curriculum. Open educational resources are educational materials that have been licensed in a way that follows the open source software or open content philosophy, and can therefore freely (at zero cost) and legally (in full compliance with copyright law) be copied, changed, and shared. Wiley (2008) describes the "4 Rs" or four basic rights one can expect to receive with an open educational resource as the rights to freely and legally:

- Reuse - Make use of the educational materials exactly as you found them (verbatim) or in an altered form.

- Revise - Adapt and /or improve the educational materials for your specific needs or circumstance.

- Remix - Combine the educational materials with other open educational resources to create new composite materials.

- Redistribute - Share the verbatim, revised, or remixed materials with others.

The Open Curriculum draws from a huge body of existing open educational resources. Some of these materials have been created specifically for high school students, like the open educational resources available from CK12. org, Curriki.org, and the National Repository of Online Courses (http://www.montereyinstitute.org/nroc/). Many other open educational resources have been created in the higher education context and need to be revised before they can be used with high school students, like the open educational resources available from MIT OpenCourseWare (http://ocw.mit. $e d u /)$, the Carnegie Mellon Open Learning Initiative (http://www.cmu.edu/oli/), and Open Yale Courses (http://oyc.yale.edu/). And while textbook costs increase at four times the rate of inflation (PIRGs, 2005), a growing number of open textbooks are becoming available (e.g., http://flatworldknowledge.com/) as well. Curric- ulum developers working for OHSU take these open educational resources as a starting point, go through a state standards curriculum alignment and gap analysis process, create missing pieces, and then assemble complete, coherent online courses.

The unique open nature of the Open Curriculum creates value both within OHSU and outside the organization. First, because the Open Curriculum is licensed in such a way that we can revise materials directly, OHSU is able to engage in a highly data-driven curriculum improvement process. As students go through the online courses, their clicks and learning paths can be tracked and recorded. This information can be combined with item response theory and learning outcome analysis data to set priorities for curriculum or assessment revision empirically. This data-driven process of curriculum improvement should allow the Open Curriculum to reach a very high level of quality very quickly.

Second, because the Open Curriculum is openly licensed, any school anywhere in the world can adapt pieces of the curriculum (or the entire curriculum) at no cost. As the quality of the curriculum improves, we anticipate unaffiliated organizations establishing Open High Schools in every state in the U.S. We also anticipate translation and localization projects rapidly making the curriculum freely available to students in other parts of the world in their own language. For example, volunteers have translated MIT OpenCourse Ware into several languages, including Spanish and Chinese, which has greatly extended its impact throughout the world. Even if adopting portions of the Open Curriculum allows the average high school to save only $1 \%$ on its traditional curriculum and textbook expenditures, the potential savings and benefit to public education are extremely significant.

Because end-of-course and other high stakes assessments cannot be shared openly without threatening the school's accreditation, OHSU may provide these assessments to organizations at a very low cost. Funds from the sales of assessments would go to furthering the development of the Open Curriculum.

\section{Innovations in Organization}

The Open High School of Utah is organizationally disaggregated into three sets of functional services: administrative services, technical services, and instructional services. By disaggregating services in this fashion, the school is able to outsource non-instructional functions and simultaneously achieve significant savings while gaining access to a broader and deeper set of expertise and services. 
Administrative services. OHSU has partnered with Academica West, Utah's oldest and largest charter services organization, for all non-instructional and non-technical services. Academica West provides a comprehensive set of management services to OHSU, including legal, financial, auditing, recruiting, and hiring services. Through the partnership with Academica West, OHSU ensures that it meets the requirements of the school's contracts, local ordinances, and state and federal laws. By offloading administrative concerns in this way, OHSU staff can focus intensely on supporting and improving student learning and not worry about the (literally) 139 different reports due to the state each year.

Learning Management System. As a virtual charter school, the Open High School of Utah's decision with regard to a learning management system (LMS) was absolutely critical, as this was the environment in which students would spend most of their time learning. The Board was looking specifically for a platform that fit with the school's passionate focus on supporting and improving student learning.

OHSU selected the GoCourse Learning System produced by Agilix (a Utah company), for a number of reasons. First, the teacher dashboards in the system visually highlight and flag students who need individual attention, allowing OHSU teachers to wake up in the morning and say "who needs a phone call for some one-on-one help today?" and have that data immediately at their fingertips.

Second, the system supports alignment of both content and assessments with state and other standards. This allows OHSU curriculum designers to design pre-assessments that can be used to determine students' paths through the courses. For example, if a student can demonstrate mastery of the assessments associated with a certain state standard, the instructional content associated with that standard can be automatically removed from the student's personalized learning path. This alignment of content and assessment with standards also makes possible OHSU's datadriven curriculum revision process.

Third, the GoCourse system has an offline client. This means that all course content can be downloaded to the laptops as part of a custom image before they are distributed to students. Students have, in effect, the whole LMS running on their local machine, and can do their course work at the virtual high school without being connected to the Internet. Whenever the laptop is connected to the Internet, it uploads all the student's previous activity and downloads any new content, including announcements. This feature is critically useful for students in rural and re- mote areas whose primary point of Internet access may be a public library or café, or students whose connections may not be very reliable.

Finally, the GoCourse system is a hosted service, meaning that-once again-administrative and technical headaches are removed from OHSU personnel who are therefore free to focus on supporting and improving student learning.

\section{Innovations in Technology}

Laptops. The Open High School committed as part of its charter to provide a laptop for each and every student that enrolls in the school. In keeping with the mantra of "focus on student learning and outsource everything else," OHSU needed more than a hardware vendor to purchase machines from-the school needed a technology partner.

The school selected DirectPointe as its laptop partner. DirectPointe (also a Utah company) is an IT outsourcing organization that works with companies in all 50 states and dozens of countries and was recently named the world's \#1 Managed Service Provider (MSPmentor, 2008).

DirectPointe handles all aspects of OHSU's laptop computing infrastructure, including purchasing the machines, creating and deploying custom images, holding laptop distribution and training events with students, and providing around the clock technical support. When a student cannot solve a problem with the overthe-phone help of a DirectPointe representative, the representative takes remote control of the laptop (with the student's permission) and fixes issues directly. If the problem still cannot be fixed, the student is immediately issued a replacement laptop and the broken machine is sent in for repair. The OHSU partnership with DirectPointe further enables the school's core staff to focus on supporting and improving student learning.

Instructional services. Outsourcing all noninstructional functions allows the OHSU to keep its staff small and highly focused. OHSU employs only a Director (Principal), the Open Curriculum development staff, and licensed teachers. This is the organizational manifestation of the mantra "focus on student learning and outsource everything else." 


\section{"Administrative and technical headaches are removed from OHSU personnel who are therefore free to focus on supporting and improving student learning."}

\section{The Future of Schools}

The Open High School of Utah's approach to building partnerships in order to outsource non-instructional functions and focus intensely on student learning may be a model for next-generation schools. In a climate where regulatory and reporting requirements are becoming increasingly arcane and time-consuming, the opportunities to make mistakes and expose a well-meaning school to legal risk are greater than ever. Neither OHSU nor any other public school can afford to directly employ an army of attorneys, auditors, and HR specialists. However, when one organization performs these functions for a number of schools they can afford to retain a large group of experts on staff, and offer their services to schools for roughly the cost of a single well-paid administrative FTE. Likewise, neither OHSU nor any other public school can afford to directly employ the same level of technical expertise in-house that can be acquired through partnerships with companies that specialize in learning management system service or IT outsourcing.

Partnerships with specialized organizations allow OHSU to become an organization that specializes in supporting and improving student learning - and that is the primary goal of the school. The cost savings and increased efficiencies of this model will likely become attractive to many schools in the future, whether brickand-mortar or virtual, and whether traditional public, charter, or private. As the number of students increases and the resources committed to our budgets decrease, we must find innovative ways to improve our services and decrease our costs.

The idea of an Open Curriculum will also likely play a huge role in the future of schools. Because taxpayers fund the schools there is a clear reason to expect that all curriculum ma- terials developed with taxpayer dollars should belong to the public who paid for them; that is, all curriculum materials produced by public schools should become part of the Open Curriculum. Similar thinking recently prompted the National Institutes of Health (NIH) to mandate that all research funded with public dollars be published in open access outlets. In their own words, "the NIH Public Access Policy ensures that the public has access to the published results of NIH funded research" (NIH, 2009). The Cape Town Open Education Declaration makes this same argument for educational materials (http://capetowndeclaration.org/).

When a district or school licenses access to online curriculum from a commercial provider, at the end of the school year (or contract term) all access to those materials is cut off, and the district is left with nothing to show for their investment. Once a sufficient amount of Open Curriculum is available for adoption and use, some districts and schools will begin to redirect their curriculum money into producing materials they will own outright, as part of "Open Curriculum Coops." When any portion of the money now spent on curriculum programs and textbooks can be redirected into teacher pay and other worthy places, students win.

We fully recognize that curriculum publishers will need to reevaluate their business models in the context of the Open Curriculum. The existence of open source operating systems like Linux and BSD has not put Microsoft completely out of business, and Apple leveraged open source software in the development of its "OS X" operating system. The Open Curriculum will likely change the ecology of the curriculum market but will only prove truly detrimental to curriculum publishers who are unwilling to adapt their business models.
Finally, virtual charters or cybercharters will have a huge role to play in the future of schools. The many virtues of virtual schools are well known, as are the many problems with online learning. But these problems can be overcome, and prudence and good stewardship demand that we attend to the potential of virtual schools to increase efficiencies and improve learning outcomes.

David Wiley is Associate Professor of Instructional Psychology and Technology at Brigham Young University, Chief Openness Officer of Flat World Knowledge, and Founder of the Open High School of Utah. He was formerly Associate Professor of Instructional Technology and Director of the Center for Open and Sustainable Learning at Utah State University. David has also been a Nonresident Fellow at the Center for Internet and Society at Stanford Law School, a Visiting Scholar at the Open University of the Netherlands, and is a recipient of the U.S. National Science Foundation's CAREER grant. His career is dedicated to increasing access to educational opportunity for everyone around the world. David lives in Utah with his incredible wife and five awesome children.

\section{References}

MSPmentor. (January, 2008). MSPmentor 100: Ranked 1 to 100. Retrieved March 13, 2009, from http://www.mspmentor. net/top-100-msps/mspmentor-100overall-rankings/

NIH. (2009). National Institutes of Health public access. Retrieved January 30, 2009, from http://publicaccess.nih.gov/

PIRGs. (2005). Rip-off 101: How the publishing industry's practices needlessly drive up textbook costs. Retrieved January 30, 2009, from http://www.maketextbooksaffordable.org/newsroom. asp?id $2=15618$

USOE. (2008). Utah charter schools-Frequently asked questions. Retrieved January 30, 2009, from http://www.usoe.k12. ut.us/charterschools/faq.htm

Wiley, D. (2008). Open education license draft. Retrieved January 30, 2009 from http:// opencontent.org/blog/archives/355 